\title{
Possibilities of integrating free and fee- based information environments in the World-Wide Web
}

\author{
S. Ntakumba \\ (Full-time student) \\ Post Graduate Diploma in Information Management \\ RAU University \\ ntakumba@yahoo.com
}

\section{Contents}

1. Introduction

2. What are the main features of free and fee-based information environments?

3. How can we integrate the free and fee-based information environments?

4. How can we integrate the free and fee-based information environments in the academic context?

5. Integrating free and fee-based information environments through value-added information services

6. Conclusion

7. References

\section{Introduction}

The information environment is a very wide terrain that has been explored by numerous people from diverse backgrounds. Various perspectives have been given as to the nature of the information environment as it stands. A distinction is usually made between information as available from printed sources on the one hand, such as newspapers, books and journals that are stored in libraries and sold in retail shops. And on the other hand, information as available electronically from electronic sources such as the Internet, CD-ROMs, etc. Though these two different environments are not mutually exclusive, the emphasis in this article is on the electronic information environment. The current period of time is commonly known as the 'Information Age'. This is mainly due to the proliferation of information and the pivotal role that information plays in the everyday lives of people, the driving force being the World-Wide Web (WWW). On the WWW, a distinction can further be made between free and fee-based information environments. This research explored those two environments based on the following question: What are the possibilities of integrating free and fee-based information environments in the Internet? 


\section{What are the main features of free and fee-based information environments?}

This question can best be answered by defining and briefly evaluating the pros and cons of both free and fee-based information environments.

\subsection{Free information environment defined}

Free Web sites are those that do not charge for the information available on them. According to Bates (1999), free Web sites include company Web pages (such as www.absa.co.za), sites maintained by publishers (such as www.bday.co.za), government agencies (such as www.wrc.org.za), trade associations and news-wire type organizations (such as www.cnnfn.com). Also useful to business are the experts - which are Web pages maintained by experts on a particular topic or industry, often providing well-organised links to key sources.

\subsubsection{Advantages of free Web sites}

The most important point about these Web sites is that they provide information free of charge to the users. Some of the information can be very valuable. For example, general news and government documents are very important for all the citizens of a country and beyond. Fosmire and Yu (2000) assessed the impact of free scholarly journals on research and came the results show that, 'overall, the free scholarly electronic journals are competitive in their quality of articles with their non-free peers, although the overall impact factors are skewed to the top and bottom. $43 \%$ were above the 75 th percentile, while $38 \%$ were below the 25th percentile.' This actually shows that the free information environment does provide some quality information in some respects.

\subsubsection{Limitations of the free Web sites}

Many Web commentators report more disadvantages of the free Web sites than advantages, even to the extent of arguing that there is no absolutely free information (Anderson 2002; Bates 1999; Kaser 2000). The vast majority of people seek free information on the Internet, but many important business and academic sources are not available for free on the Web. Bates (1999) further points out that one of the most frustrating things in the free information environment is that there is no ability to aggregate searches; the researcher must go from site to site, gathering information. In addition, free Web sites usually do not offer substantial archives of information; an article that was available one week may be gone a week later. Many Web sites offer only limited search functionality beyond the ability to combine two words with an AND or an OR. Search engines are normally used to search for free information. They normally deliver a lot of irrelevant information instead of specific ones.

\subsection{What are fee-based Web sites?}

Fee-based Web sites are those that offer copyright material such as full-text articles or indexes consisting of abstracts to articles, as well as other high-quality information such as trade statistics, or company financial statements. These companies charge for access to their information - either by an annual access fee or each time a user downloads a document. Examples include ScienceDirect (www.sciencedirect.com), Emerald (www.emeraldinsight.com), and database hosts (information aggregators) such as The Dialog Corporation (www.dialog.com), STN (http://www.stn-international.de) or Factiva (www.factiva.com). Most provide password subscription for access.

\subsubsection{Advantages of fee-based Web sites}


The major advantage of fee-based Web sites is that they usually provide an archive of materials dating back some years. For example, the ScienceDirect site has an archive of fulltext journals dating back as far as five years ago. The Mail and Guardian Web site provides an online e-mail subscription where it also gives an index of previously published articles related to the news item you may be reading at that point in time. Fee-based Web sites usually offer a power search option, enabling users to focus their searches more precisely, and they provide access to information that is not available in the free information environment, mainly newspaper and journal articles. They also offer preformatted collections of information, particularly company profiles and statistical information.

\subsubsection{Disadvantages of fee-based Web sites}

One of the major drawbacks of these fee-based sites is that they encourage ad hoc purchases of information, leading to redundancy. They often require researchers to charge the expenses to their personal credit cards. In fact, some of these fee-based sites require that users provide a credit card for payment; others offer the ability to pay by subscription, purchase orders or other auditable methods. While fee-based sites provide a better selection of material than free Web sites, they are still limited in their focus. Most offer one type of information - company information, or general newspaper articles, or investment related reports - but to find a comprehensive selection of business information, the researcher still has to access several different sources (Bates 1999). In Table 1 is a comparison of the attitudes of American workers toward free versus fee-based information.

Table 1 Free versus fee-based information services (adapted from Outsell Inc 2001)

\begin{tabular}{|l|c|c|}
\hline $\begin{array}{l}\text { Question about free vs } \\
\text { Fee-based services }\end{array}$ & Free services & Fee-based services \\
\hline $\begin{array}{l}\text { Which service supplies } \\
\text { higher quality } \\
\text { information? }\end{array}$ & $44 \%$ & $47 \%$ \\
\hline $\begin{array}{l}\text { Which service provides } \\
\text { information that helps you } \\
\text { make mission-critical or } \\
\text { high-risk decisions? }\end{array}$ & $38 \%$ & $52 \%$ \\
\hline $\begin{array}{l}\text { Which service provides } \\
\text { information that you use } \\
\text { to make daily decisions? }\end{array}$ & $74 \%$ & $19 \%$ \\
\hline $\begin{array}{l}\text { Which service provides } \\
\text { information that you use } \\
\text { and trust without } \\
\text { verification? }\end{array}$ & $50 \%$ & $41 \%$ \\
\hline $\begin{array}{l}\text { Which service contains } \\
\text { information from credible } \\
\text { and known sources? }\end{array}$ & $53 \%$ & $39 \%$ \\
\hline
\end{tabular}

Based on the above results, it is clear that both environments have their own strengths and weaknesses according to user's attitudes. This justifies an approach that will not promote one more than the other, but one that seeks to integrate the two. 
Access to Internet-based information has become an accepted part of most people's lives, especially in the academic and commercial sectors. In the academic field researchers are mainly interested in journals and archives that are usually stored in online databases.

Academic libraries and individuals ensure that they have access to the best information sources found in the Internet for their respective fields. In the commercial sector businesses are mainly interested in basic information for decision making, marketing of their products and services, and general business transactions. To have your own Web site has become a major way for companies to claim their place in the information environment. Electronic business or e-commerce has become a buzzword. In this article an attempt is made to answer the above stated question in the context of information environment as it relates to business and academic fields.

\subsection{Integration of free and fee-based information environments in the e-business context}

The Internet, through the World-Wide Web, has become a commercial medium and a fast growing market place. It is providing a direct link between commercial firms and their customers. Even in this context one gets both free and fee-based information environments. The initial step by firms is to make themselves known to their customers by providing some basic information free of charge. The second step is to provide subscription and fee-based access to its products and services. Hoffman, Novak and Chatterjee (2002) present an initial attempt to organise the commercial activity on the Web. In the context of their framework, they identify two major categories of sites: 'destination sites' and 'Web traffic control sites'. Under destination sites they identify online store fronts, Internet presence sites and content sites. Hoffman et al. (2002) further argues that the purpose of the Web traffic control sites is to direct consumers to these various destination sites. There are three major categories of Web traffic control sites: malls, incentive sites and search agents. Although their framework is located in the context of 'integrated marketing', in which various communication vehicles are coordinated to create a single, strategically appropriate effort, it is a good example of how free and fee-based information environments can be integrated. In the following discussion, one example from each category is used to illustrate the point.

\subsection{Integration through content sites}

Content sites are divided into fee-based, sponsored and searchable databases. In fee-based content sites, the provider supplies and/or pays for content which the consumer pays to access. As the name indicates, such a site is part of the fee-based information environment and it faces the challenge of consumers being unwilling to pay for the content delivered in this manner. As a way of integrating with the free information environment, Hoffman et al. (2002) note that the recent trend is toward information-brokering, as with www.netshare.com, and usage-based pricing, as with www.newspage.com where visitors are able to access news summaries at no charge, but incur a small fee for the full text of a story.

Sponsored content sites sell advertising space to reduce or eliminate the necessity of charging fees to visitors. They usually provide sponsored entertainment content and sponsored search agents. Examples of sponsored content sites include www.Triangleonline.com, www.Pathfinder.com, www.Washingtonian.com, and others. As the name indicates, the consumers get the information free of charge and sponsors foot the bill.

In searchable databases, advertisers pay a provider for information placement in an organised listing. It is the inverse of a fee-based content model. At the end of the day the consumer pays very little or no fee at all for the service received. Examples include, Table- 
of-contents, Inc, Single-search, and so forth. Users get motivated to take a further step of buying the product if they have some basic information in their disposal.

\subsection{Integration through search agents}

The purpose of search agents is to identify other Web sites through a keyword search of a database that extends throughout the Web. According to Hoffman et al. (2002), a recent trend in such sites is the emergence of fee-based (e.g. Infoseek) or advertiser-sponsored (e.g. Yahoo) search agents. Given that character, search agents have both features of free and feebased information environments. The fee-based search agents also give a minimum amount of information free of charge, and thereafter they expect the user to pay to access in-depth information. It is easy to confuse search agents with traditional search engines. Hermans (1996) makes the following distinctions between the two:

- Agents are able to take into context the words the user is searching for, unlike a search engine which searches only for keywords. It includes using a tool such as a thesaurus which is able to look for the alternative meanings of words.

- Agents are able to search for a longer period and are able to gather information without the user taking the time to do so. A search engine takes up time as the user has to specifically inform the engine of the information and sometimes do a second search if the information is irrelevant.

- Agents are able to do pre-emptive searches which will often provide information that the user was not specifically looking for but is relevant to the users interests, or will provide specific information that the user searched for earlier.

Although it is difficult to search anything on the Web due to the proliferation of commercial Web sites, search agents do provide some form of integration between the free and feebased information environment. The advertiser-sponsored ones are more prominent in this regard.

\subsection{Reducing barriers to consumer adoption of fee-based Web sites}

Another method of integrating free and fee-based information environments could be by way of reducing barriers to consumer adoption of fee-based sites. Such barriers are the shortcomings of fee-based sites as stated before. Hoffman et al. (2002) report that accumulated industry experience and anecdotal evidence strongly support the notion that the primary barriers to consumer adoption of the Web as a commercial medium are ease of use, price and risk, including such factors as privacy and security.

\subsubsection{Ease of use}

Ease of use includes matters such as the user-friendliness of the software, ease of software installation, and the like. Fee-based sites tend to be much better than free sites in this regard, but users require an initial access for them to use such sites. To eliminate this barriers, feebased sites will have to provide more access to their sites. That can be done through marketing of their products in the free information environment and conducting consumer surveys that seek to investigate what users would prefer as the best way of accessing a site. Giving free online tutorials about how to use the site could serve as a good integrating method. After engaging in a tutorial, users might find it easier to access information products and services of a commercially based site they deem to be user-friendly. Userfriendliness has an advantage of saving time and being convenient. As Seaman (1995) puts it, 'attempts to develop technology that is user-friendly are as important as the development of the technology itself'. 


\subsubsection{Price}

Some Internet users are willing to pay but the barrier becomes the price of the product or service that is being rendered through the Web site. Since providers save a lot of costs by eliminating the middleman, transportation costs, and so forth, they need to keep prices as low as possible. Price is the major attraction or impediment to potential customers. The cheaper it is to get information from fee-based sites, the easier it will be to attract consumers who are traditionally used to free information.

In the free sites, consumers have a benefit of comparing prices as a way of evaluating their decisions. According to Ranganathan and Granapathy (2002), research studies have shown that decision aids have a favourable effect on the quality of online purchase decisions. Many Web sites such as www.excite.com and www.mysimon.com offer decision aids for making product-price comparisons. Through www.dells.com site, a consumer can custom-build a computer and make price comparisons for various computer configurations. There are also Web sites such as www.priceline.com that offer decision aids like a calendar that are useful in the decision-making process.

Price may also involve the type of monitory currency that is used for buying. Most sites require users to pay in US dollars or Euros. The exchange rate between such currencies and the currencies of less developed economies are very unequal. At the same time, most consumers are not economically literate enough to know the relevant exchange rates and their implication. The moment they discover that, for instance, 1US\$ means R10 it can scare them away. It is therefore important for fee-based Web sites to provide as many currency options as possible.

\subsubsection{Risk}

As stated in the above discussion, risk includes such factors as privacy and security. Free Web sites provide information free of charge while fee-based Web sites require payment, which is usually electronic in nature. Users are sceptical of conducting such transactions, particularly with people whom they will never meet physically. Liu and Arnett (2000) argue that customers would not pay for products or services over the Web if financial information could not be transmitted securely. Fee-based Web sites can give the option of downloading payment forms for consumers to pay over-the-counter in their nearest financial institutions instead of using credit cards. Cheques and telephonic transaction can also serve a similar purpose.

Most commercial Web sites also require users to provide personal details. Consumers are unwilling to reveal personal information over the Web, despite assurances given by online merchants (Ranganathan and Ganapathy 2002). It is recommended that if such information is really important for the service provider, reasons must be stated and an alternative way of giving it should be provided. Methods like snail mailing, faxing or filling-in forms in nearest banks can be explored. According to IITA (1994) there is great concern regarding the security of financial information transmitted over the Internet and its impact on consumer willingness to buy or sell products.

\section{How can we integrate free and fee-based information environments in the academic context?}

The suggestions that have been made about possibilities of integrating free and fee-based information environments as it relates to e-business also apply in the academic context. 
However, the role of databases of books, scholarly journals and archives needs particular attention. Kaser (2000) identified two basic models for funding information services: either those who use it pay to use it or those who produce it find some other funding means to support its production. This pay-for-use model and pay-to-produce model fit in well with the academic context. In this section, the author demonstrates how these models can be applied to integrate free and fee-based information environments. Secondly, provision of online scholarly journals to academic libraries are used as another example to demonstrate the possibilities of this integration.

\subsection{Pay-for-use model}

In this model, the individual user pays, or his/her institution pays, or a network of institutions which has banded together into a buying collective pays or, in the case of government information, the taxpayer pays a marginal cost. Given the widely held perception that information should be free, such indirect means can help integrate free and fee-based environments. Library users pay some form of subscription or library use fee to access its services. The library subscribes to database hosts on behalf of its users. The users access information free of direct charge through institutional intranets and gateways. In that way, the fear of insecurity, provision of personal details to Web sites, and inconvenience is completely addressed.

\subsection{Pay-to-produce model}

In this model, the association, charity, or university pays to produce and distribute an information product out of member dues, donations, tuition fees, trusts, or other income. Kaser (2000) further illustrates this model by using the example of radio and television where advertisers pay to make the information being distributed via these media 'look' free. In South Africa, for instance, access to government and government affiliated information resources is subsidised. Institutions of learning provide infrastructure for members to access such information. Buckely et al. (1999) published a bibliographic essay of current issues on electronic publishing of scholarly journals, in which he reviewed such issues as access, cataloguing and indexing, pricing, archiving, and licensing. Some of these issues is also dealt with here to demonstrate how they can be used to integrate free and fee-based information environments in academia.

\subsection{Access to journal information}

Buckely et al. (1999) stated that when it comes to accessing electronic journals there are many issues for libraries to consider: technology requirements, restricted access, access via publisher or aggregator, and making library patrons aware of on-line access. It is important for libraries to have access to electronic journals because of the ease of use and universal acceptance of technology. Libraries should find the easiest ways of giving users access to electronic information. Aggregators conglomerate journals of several publishers under one interface and in one search system, for example, the www.sciencedirect.com Web site. If academic institutions subscribe to it, it makes it easier for their members to have access to a plethora of scholarly journals. Odlyzko (1994:4) proposes preprints as a solution, with scholars sending their preprints to a central database which anyone can access via Ftp.

\subsection{Pricing of journal information}

Various pricing models are proposed by various authors to integrate free and fee-based information environments. One model is where the current issue would continue to be distributed free online while back issues would be provided with value-added features such as a search engine, and have a charge added. The freely provided information would serve to 
market the journal and users would have a reason to pay for such information because they know it. In another model librarians would prefer to be charged only a percentage of the print price for electronic access to the journal. Meyer (1997) described other solutions that have been attempted by librarians. One is that of access instead of ownership, that is, using document delivery services to provide articles on an individual basis instead of subscribing to a journal. Another is putting together consortia of libraries to provide access to sets of electronic journals. And the last is the creation and maintenance of archives of electronic journal articles without reference to commercial publishers. Such methods can provide easier means of accessing scholarly journal information without necessarily closing down the services of fee-based Web sites.

\section{Integrating free and fee-based information environment through value-added information services}

In addition to free and fee-based information environments, value-added information services are being introduced as the third type of information environment. Based on the studies conducted by various authors on this kind of information environment, it is suggested here that value-added information services can act as an integrating agent between free and fee-based information environments. Anderson (2002) described valueadded information services as offering high quality information from a wide variety of sources including news wires, newspapers, magazines, journals, and other sources. They have extensive archives of periodicals and historical financial data. They offer simple but powerful tools, and results can be downloaded, printed or e-mailed. They also offer electronic clipping features which keep researchers informed about topics they select. As stated before, one of the disadvantages of a free information environment is the lack of standardization and its inability to aggregate searches, which means that much of the information is useless. Fee-based sites on the other hand are too focused and limited in scope. The features of the value-added information service actually address such limitations. A study conducted by Bates (1999) compared the three information environments and produced the results presented in Table 2.

Table 2 Some features and benefits of on-line information resources (Bates 1999)

\begin{tabular}{|l|l|l|l|}
\hline Feature/Benefit & $\begin{array}{l}\text { Company Web } \\
\text { sites (e.g. Edgar) }\end{array}$ & $\begin{array}{l}\text { Fee-based sources } \\
\text { (e.g. Hoover's) }\end{array}$ & $\begin{array}{l}\text { Value-added } \\
\text { service (e.g. Dow } \\
\text { Jones Interactive) }\end{array}$ \\
\hline $\begin{array}{l}\text { Reliability, } \\
\text { authority }\end{array}$ & $\begin{array}{l}\text { Content in } \\
\text { company Web sites } \\
\text { is primarily } \\
\text { promotional. Most } \\
\text { Web sites do not } \\
\text { have editorial } \\
\text { standards. }\end{array}$ & $\begin{array}{l}\text { Most fee-based } \\
\text { sources provide } \\
\text { access to edited } \\
\text { material. Limited } \\
\text { sources, none } \\
\text { provide access to } \\
\text { Dow Jones } \\
\text { publications. }\end{array}$ & $\begin{array}{l}\text { Dow Jones } \\
\text { Interactive (DJ) } \\
\text { provides the } \\
\text { combined editorial } \\
\text { skills of Dow Jones } \\
\text { and Reuters editors } \\
\text { and of the top } \\
\text { respected sources } \\
\text { of the business and } \\
\text { industry press. }\end{array}$ \\
\hline Updated, archived & $\begin{array}{l}\text { It is often } \\
\text { impossible to } \\
\text { determine when a } \\
\text { site was last } \\
\text { updated. There is }\end{array}$ & $\begin{array}{l}\text { Updating can be } \\
\text { sporadic. Most } \\
\text { provide a moderate } \\
\text { amount of } \\
\text { archiving. }\end{array}$ & $\begin{array}{l}\text { Information is } \\
\text { continually } \\
\text { updated; articles } \\
\text { are added as soon } \\
\text { as they are made }\end{array}$ \\
\hline
\end{tabular}




\begin{tabular}{|l|l|l|l|} 
& $\begin{array}{l}\text { no assurance that } \\
\text { material found one } \\
\text { day will be } \\
\text { available later. }\end{array}$ & $\begin{array}{l}\text { available by the } \\
\text { publisher. } \\
\text { Extensive archives, } \\
\text { often going back 10 } \\
\text { years. }\end{array}$ \\
\hline Aggregated & $\begin{array}{l}\text { No aggregation. } \\
\text { Each information } \\
\text { source must be } \\
\text { located and then } \\
\text { searched } \\
\text { separately. }\end{array}$ & $\begin{array}{l}\text { Sources can be } \\
\text { searched } \\
\text { simultaneously; } \\
\text { however, most fee- } \\
\text { based services } \\
\text { provide limited } \\
\text { selection of } \\
\text { sources. }\end{array}$ & $\begin{array}{l}\text { All sources can be } \\
\text { searched } \\
\text { simultaneously; DJI } \\
\text { offers one of the } \\
\text { widest variety of } \\
\text { business } \\
\text { information } \\
\text { sources. }\end{array}$ \\
\hline Updating & $\begin{array}{l}\text { No useful ability to } \\
\text { be notified when } \\
\text { relevant material } \\
\text { has been added to a } \\
\text { Web site. }\end{array}$ & $\begin{array}{l}\text { Electronic clipping } \\
\text { services are not } \\
\text { available on most } \\
\text { fee-based services. }\end{array}$ & $\begin{array}{l}\text { DJI offers } \\
\text { CustomClips, } \\
\text { which deliver } \\
\text { highly targeted } \\
\text { information from a } \\
\text { wide variety of } \\
\text { sources. }\end{array}$ \\
\hline $\begin{array}{l}\text { High value: cost } \\
\text { ratio }\end{array}$ & $\begin{array}{l}\text { Direct costs; time } \\
\text { required by } \\
\text { researcher is } \\
\text { significant. }\end{array}$ & $\begin{array}{l}\text { No. Costs are often } \\
\text { no lower than } \\
\text { value-added } \\
\text { services, but fewer } \\
\text { information } \\
\text { services and } \\
\text { features are } \\
\text { available. }\end{array}$ & $\begin{array}{l}\text { Yes. DJI provides } \\
\text { wide selection of } \\
\text { high- quality } \\
\text { information sources } \\
\text { and tools that } \\
\text { enable efficient } \\
\text { searches, at a } \\
\text { reasonable price. }\end{array}$ \\
\hline
\end{tabular}

The results of this study showed significant differences among the three approaches. In almost every case, better answers were available only through the value-added service. Value-added services circumvent the problems cited by Wan (2000), namely that many Web sites (both free and fee-based) do not incorporate features that exploit the unique capabilities of the Internet; they lack navigation tools that could help visitors find the site and assess its beneficial features; and other promotional media (i.e. print) are seldom integrated with online strategies.

\section{Conclusion}

The above discussion has provided an insight into two major kinds of information environments, namely free and fee based. An attempt has been made to illustrate the possibilities of integrating the two information environments in the contexts of electronic business and academia. E-business and academic contexts represent the two major sectors involved in the use of information available on the Internet. Lastly, a third kind of information environment, called value-added information services, has been presented as another possibility that can integrate free and fee-based information environments. In conclusion, users are warned that so much is already available in the Web and so much is added every moment that it creates the impression that everything that could be needed is on-line. Kovacich (2000) confirms this point by reporting that one author coined the term 'net disease' which he characterized as 'a condition that allows otherwise rational business people to think that competitive intelligence begins and ends with the World-Wide Web', 
that 'if the data [are] not on the Net or in databases, then [they] probably cannot be found at all'. Internet-based information should not be seen as an end in itself, but a means to an end.

\section{References}

Anderson, D. [ed.] 2002. Free, fee-based and value-added information services. [Online]. Available WWW:

http://www.bestofboth.com/collateral/files/whitepaper_feevsfree_032002.pdf.

Bates, M.E. 1999. Selecting business intelligence sources: The public Web vs. value-added online services. [Online]. Available WWW: www.factiva.com/infoPro/BusIntellletter.pdf.

Buckley C. et al. 1999. Electronic publishing of scholarly journals: a bibliographic essay of current issues. [Online] available WWW:

http://dois.mimas.ac.uk/DoIS/data/Articles/upvsteliby:1999:v:25:i:5:p:5.html.

Fosmire, M. and Yu, S. 2000. Free scholarly electronic journals: how good are they? Issues in science and technology librarianship. [Online]. Available WWW: http://www.istl.org/00fall/Internet.html.

Hermans, B. 1996. Intelligent software agents on the Internet: an inventory of currently offered functionality in the information society and a prediction of (near-future) developments. Tilburg University. [Online]. Available WWW:

http://www.kub.nl/academics.

Hoffman, D.L., Novak, T. and Chatterjee, P. 2000. Commercial scenarios for the Web: opportunities and challenges [Online]. Available WWW:

http://www.ascusc.org/jcmc/vol1/issue3/hoffman.html.

IITA. 1994. Electronic commerce and the NII. Information Infrastructure Technology and Applications Task Group, National Coordination Office for High Performance Computing and Communications (February):13-4.

Kaser, R.T. 2000. If information wants to be free ... then who is going to pay for it? D-Lib Magazine 6(5). [Online]. Available WWW: www.dlib.org/dlib/may00/kaser/05kaser.html.

Kovacich G.L. 2000. Pages netspionage - the global threat to information, Part I: what is it and why I should care? In Computers and Security 19(4):326-336. [Online]. Available WWW:

http://www.sciencedirect.com/science?_ob=ArticleURLand_udi=

B6V8G-4118JYH-10and_user=736737and_coverDate $=07 \% 2 F 0$

1\%2F2000and_alid=46359787and_rdoc=3and_fmt=full.

Liu, C. and Arnett, K.P. 2000. Exploring the factors associated with Web site success in the context of electronic commerce. Information and Management 38(1):23-33. [Online].

Available WWW: http://www.sciencedirect.com/science?_ob=ArticleURLand_udi =B6VD0-411XCPG-3and_user=736737.

Meyer, R.W. 1997. Monopoly power and electronic journals. Library Quarterly 67(4):325349.

Odylzko, A. 1994. Tragic loss or good riddance? The impending demise of traditional 
scholarly journals. International Journal of Human-Computer Studies 42(1):71-122.

[Online]. Available WWW: ftp://netlib.att.com/netlib/att/math/odlyzko/tragic.loss.Z.

Outsell Inc. 2001. Super I-AIM. Performance computing and communications (September):13-4. [Online]. Available WWW:

http://www.eff.org/Misc/Publications/Declan_McCullagh/www/global/g71995/US/SUMEC.TXT.

Ranganathan, C. and Ganapathy, S. 2002. Key dimensions of business-to-consumer Web sites. Information and Management 39(6):457-465. [Online]. Available WWW: http://www.sciencedirect.com.

Seaman, B. 1995. The future is already here. Time (Spring):30-33. [Online]. Available WWW: http://204.29.171.80/framer/navigation.asp?charset=utf-8andcc=USandframeid $=1565$ andlc $=$ en-

usandproviderid=113andrealname $=$ Time + Magazineanduid $=1722286 \mathrm{andurl}=\mathrm{http} \% 3 \mathrm{~A} \%$ 2F\%2Fwww.time.com.

Wan, H.A. 2000. Opportunities to enhance a commercial Web site. Information and Management 38(1):15-21. [Online]. Available WWW:

http://www.sciencedirect.com/science?_ob=ArticleURLand_udi=B6VD0-411XCPG.

\section{Disclaimer}

Articles published in SAJIM are the opinions of the authors and do not necessarily reflect the opinion of the Editor, Board, Publisher, Webmaster or the Rand Afrikaans University. The user hereby waives any claim he/she/they may have or acquire against the publisher, its suppliers, licensees and sub licensees and indemnifies all said persons from any claims, lawsuits, proceedings, costs, special, incidental, consequential or indirect damages, including damages for loss of profits, loss of business or downtime arising out of or relating to the user's use of the Website. 